\title{
Souvislosti partnerství a mateřství: Vliv partnerského vztahu na rozhodování žen o mateřství
}

\author{
Relationships and Motherhood: The Influence of Relationships \\ between Men and Women in Decision-Making on Motherhood
}

Michaela Kvapilová Bartošová

\begin{abstract}
According to the attitudes of young people, parenthood is ideally realised as a part of a stable relationship and as a decision shared by both partners. The relationship between a man and woman is a crucial condition of parenthood and the absence of it could be an important barrier to entry into the parenthood phase. This paper summarises one part of the results of a qualitative research project focused on decision-making about motherhood in the case of first births over thirty and their childless peers. The issue of decision-making about motherhood was observed from the perspective of relationships. The analysis shows that the influence of relationships on the decision about motherhood is rather indirect: 1) mate preferences changed over time and with the priorities of different life stages, 2) important to ideas about the relationship is the gender dimension, mostly in reference to the division of household labour, and 3) the overall approach to relationships results from the maternal preferences of women.
\end{abstract}

KEYWORDS motherhood, relationships, gender roles, life course, post-adolescence

I navzdory změnám v oblasti partnerských a intimních vztahů je (št'astné) partnerství stále považováno za jeden $\mathrm{z}$ hlavních předpokladů plánovaného rodičovství. Žen, které se vlastní volbou stávají matkami samoživitelkami, je méně než těch, které se matkami bez partnera staly nedobrovolně, následkem různých životních okolností (Hamplová 2007). Výzkum neprovdaných matek ukázal, že navzdory různorodosti důvodů pro mimomanželské mateřství většina z nich označila za ideální formu partnerského soužití manželství (Chaloupková 2007). Rodičovství mimo manželství představuje pro velkou část neprovdaných matek pouze novou fázi rodinné dráhy spíše než celoživotní strategii. Zvyšující se podíl dětí narozených mimo manželství je $\mathrm{v}$ mnoha případech dán prodlužováním nesezdaného soužití na dobu po narození dítěte (Chaloupková 2011). Rodičovství se zdá být spíše než individuálním projektem záležitostí vztahovou - dítě znamená sdílenou odpovědnost a jeho narození by měla předcházet snaha o zajištění kvalitního vztahu (Sevón 2005).

Partnerský závazek se však stal v průběhu posledních desetiletí na rozdíl od rodičovského podstatně snáze zrušitelným, a tedy i křehkým a nejistým. Zatímco dř́ve bylo

Sociálni studia. Katedra sociologie FSS MU, 4/2011. S. 67-86. ISSN 1214-813X.

1 Tato studie vznikla s podporou Ministerstva školství, mládeže, a tělovýchovy - výzkumný záměr „Reprodukce a integrace společnosti“ (MSM0021622408). 
partnerství (manželství) a rodičovství nedílně spojeno, jedno následovalo druhé a oba závazky se vzájemně posilovaly, dnes zejména partnerství získává zcela jinou podobu a odděluje se od rodičovství jako zkušenost specifického charakteru. Z hlediska perspektivy životního běhu je třeba mluvit spíše než o partnerství o partnerstvích, jejichž obsah i forma se mohou lišit vzhledem ke kontextu a věku, ve kterých jsou realizována.

Jedním z výrazných znaků této změny je nárůst počtu alternativních partnerských uspořádání, především nesezdaného soužití. Lidé považují kohabitaci za flexibilnější a nezávaznější formu soužití, než je manželství, umožňující promýšlet výhody nebo nevýhody manželství (Kravdal 1999). Ti, kdo žijí v nesezdaných soužitích, zastávají méně tradiční postoje k rodině, jsou tolerantnější k rozchodu (Clarkberg a kol. 1995) a volí tuto formu soužití, aby si uchovali větší nezávislost a vyhnuli se obavám ze ztráty samostatnosti v př́padě manželství (Barlow a James 2004). Těmto postojům odpovídá i nižší stabilita kohabitací oproti manželstvím (Seltzer 2000), což potvrzují i nejnovější česká data (Vohlídalová a Maříková 2011). Nárůst počtu kohabitujících jedinců i fakt častějšího rozpadu nesezdaných soužití ve srovnání s manželstvím nemusí nutně znamenat odmítání dlouhodobých partnerských závazků. Zejména $\mathrm{v}$ období před rozhodnutím o rodičovství může otevřenost různým partnerským zkušenostem poukazovat na potřebu hledání toho správného vztahu a hledání vlastní identity ve vztazích. Jak podotýkají Vohlídalová a Maříková (2011), tento proces sice zvyšuje riziko rozpadu kohabitujících vztahů, ale na druhou stranu může zvyšovat i kvalitu vztahů a vést k větší pravděpodobnosti přežití manželství vzniklých po předchozí kohabitaci.

Vzhledem k rozšířenosti alternativních typů soužití a akceptaci dočasnosti vztahů může být proces hledání toho správného vztahu komplikovaný a dlouhodobý. Pokud je „správné“ partnerství přijímáno jako předpoklad vstupu do rodičovství a rodičovství vnímáno jako sdílená odpovědnost, stává se absence takového partnerského vztahu významnou bariérou rodičovství - důvodem jeho odkládání nebo preference bezdětnosti. Zatímco v tradiční společnosti měly na ne/existenci partnerství (manželství) vliv spíše vnější okolnosti, dnes je tato skutečnost výsledkem individuálního jednání, záměrů a voleb, respektive je tímto způsobem normativně (re)prezentována: Vnější sociální a ekonomické podmínky a kulturní normy vytváŕí kontext, v němž jsou lidé nuceni činit vlastní individuální volby a rozhodnutí. Jedinci se již více nerodí do sociálně určených situací, ale musí vytvářet své životy ve vztahu k překážkám a př́ležitostem nastolovaným novými institucemi, jako jsou pracovní trh, sociální stát a vzdělávací systém (Beck-Gernsheim 2002). V prŕípadě zvažování rodičovství v souvislosti s partnerstvím mohou být rozhodnutí mladých lidí komplikovaná právě pro odlišný charakter obou. Za jakých podmínek, kdy a zdali vůbec spojit z podstaty nejisté partnerství s téměř nezrušitelným rodičovstvím? Které partnerství (kterého partnera/partnerku) považovat za vhodného nejen k partnerství, ale i k rodičovství? A jak tuto volbu vyjednat ve vzájemném vztahu dvou individuí? Posun v časování rodičovství do pozdějšího věku a prodlužování období, ve kterém jsou mladí lidé bezdětní, otevírá možnost zakoušet různé partnerské zkušenosti. Zdali a jak se tyto zkušenosti odráží v rozhodování o dítěti a v časování rodičovství, není ve výzkumech hlouběji reflektováno.

Následující text shrne v první, teoretické části kontext, v němž mladí lidé uvažují o partnerských vztazích a rodičovství, a ve druhé, empirické části se na př́ikladu kvalitativního výzkumu zaměřeného na prvorodičky a bezdětné ženy starší třiceti let pokusí ukázat, jakými 
způsoby a za jakých okolností se může stát partnerství bariérou mateřství. Výzkum byl primárně orientován na různé souvislosti rozhodování o mateřství a partnerský vztah se ukázal být jedním z klíčových faktorů tohoto myšlenkového procesu. Ve všech př́ípadech zkoumaných žen je ideální rodičovství realizováno jako součást „spokojeného“ partnerského vztahu. Nedá se přitom říct, že by ženy dokázaly vždy definovat konkrétní vlastnosti vhodného otce dítěte nebo popsat důvody možné absence či rozpadu partnerského vztahu jako potenciálních bariér mateřství. Rozhovory nicméně ukázaly, že 1) partnerské preference se mění s věkem a s prioritami vztahujícími se k určitým životním obdobím, 2) důležitou součástí uvažování o vztahu je jeho genderová dimenze odrážející se zejména $\mathrm{v}$ rozdělení rolí $\mathrm{v}$ domácnosti, a 3) celkové pojetí partnerského vztahu se odvíjí od mateřských preferencí žen. Analytické kapitoly jsou věnovány těmto třem tématům, která různými zpo̊soby akcentují vztah mezi partnerskými vztahy a rozhodováním o mateřství.

\section{Změna v charakteru a uspořádání partnerských vztahů a bez/dětnost}

Rozhodování o rodičovství souvisí bezprostředně s měnícím se charakterem partnerských a intimních vztahů. Transformaci intimity popisuje Giddens (1992) ve svém konceptu čistého vztahu nebo podobným, i když jiným způsobem např́klad Singly (2001a), který mluví o partnerském modelu ,život ve dvou v napětí““. ${ }^{2} \mathrm{~V}$ obou prípadech je prokreativní role vztahu upozaděna a vlivem individualizace se v intimní sfére střetávají dva nezávislí jedinci, které k sobě váže důvěra $v$ jedinečnost partnera, pouto sexuální přitažlivosti, emotivní komunikace a určitá citová exkluzivita. Závazek daný povinností, př́ibuzenstvím či tradicí je nahrazován náročněji udržitelným a nestabilnějším poutem vzájemné lásky, které je výsledkem volby svobodného individua. S rostoucí individualizací se potřeba blízkého vztahu neztrácí, ale je naopak posilována (Beck a Beck-Gernsheim 1995). Jedinec od blízkých vztahů očekává především autenticitu, pocit svobody v páru, ochranu před existenciální nejistotou a potvrzování sebe sama a vlastní identity pomocí druhého (Singly 2001b).

Prolomení mnoha tradičních jistot daných věkem, pohlavím nebo sociální třídou a nutnost konstruovat vlastní biografii samostatně, i když zároveň v závislosti na podmínkách pracovního trhu a požadavcích sociálního státu, pak mohou vést k odložení vstupu do tradičních institucí manželství a rodiny až po zvážení všech individuálních rizik (Beck 1992). Ekonomická nejistota a narůstající individualizace rizik jsou asociovány s poklesem fertility. Změny v partnerství a rodičovství nejsou z tohoto pohledu přisuzovány měnícím se individuálním preferencím nebo hodnotám. Nejistými se stávají spíše měnící se ekonomické okolnosti, které se podílí na utváření dlouhodobých cílů, jako je například určitý stupeň nezávislosti jako předpoklad vstupu do rodičovství (Oppenheimer 1994). Míra rizika v rychle se měnícím kontextu se může lišit v závislosti na pohlaví. Bezdětnost nebo i život bez partnera jsou spojovány s narůstající ekonomickou nejistotou způsobenou globální restrukturalizací

2 Singly (2001a, citován in Dudová a Vohlídalová 2005) polemizuje s Giddensem (1992) a odmítá představu vztahu zcela osvobozeného od vnějších závazků. Lidé očekávají od partnerského vztahu pocit bezpečí a jistoty, a to i přesto, že zároveň od jeho počátku ví, že je kdykoliv zrušitelný. Určitá jistota vztahu je dána přesvědčením o výlučnosti partnera a potvrzována sexuální věrností. 
sociálního státu, která znamená oslabení živitelské role muže a ženy vede k uvědomění si rizika spojeného s ekonomickou závislostí na muži (Hobson a Olah 2006, Lewis 2006). Uceleně poukazují na problematiku genderové asymetrie jako důležitého faktoru poklesu fertility zejména práce McDonalda (2000a, 2000b), podle kterého je nízká porodnost výsledkem vysoké genderové rovnosti v institucích orientovaných na jednotlivce a přetrvávající genderové nerovnosti v rodinách. Ženy sice dosahují podobných pozic jako muži ve sférée vzdělání a práce, nicméně principy tradičního živitelského modelu stále podepírají sociální instituce orientované na rodinu, jako jsou veřejné služby, systém sociálních dávek a rodina samotná.

Stále frekventovanější „nové“ formy partnerských vztahů (nesezdané soužití, oddělené soužití, otevřené vztahy) poskytují potřebnou míru nezávislosti a nezávaznosti, umožňující skloubit biografii řízenou požadavky trhu a potřebu „,významných druhých“ (Bauman 2002, Roseneil a Budgeon 2004). Ze své podstaty mohou tyto vztahy také více podporovat bezdětný životní styl. Podle výzkumného projektu Proměny prováděného Sociologickým ústavem AV ČR v letech 2004-2009 se ukázalo, že lidé preferující „netradiční“ typy soužití a uspořádání soukromého života upřednostňují zároveň život bez dětí nebo s menším počtem dětí než ostatní. Tato tendence může být posílena i určitou sociální dědičností - socializace $\mathrm{v}$ neúplné rodině může vést $\mathrm{k}$ opakování tohoto modelu v dospělosti nebo k preferenci menšího počtu dětí (Hašková 2005).

V souvislosti se zvyšující se diverzitou rodinných a intimních vztahů se mění význam rodiny jako takové. Rodina již nemusí být vnímána jako seskupení osob spojených pokrevním př́ibuzenským svazkem, ale je naplňována subjektivně konstruovanými významy. Ty umožňují rozšiřiit škálu praktik a vztahů, jejichž prostřednictvím je rodina prožívána. Lidé stále častěji „,utváříi“ rodinu (,,doing “ family) na základě osobních preferencí a voleb (Silva a Smart 1999, Smart a Neale 1999, Budgeon a Roseneil 2004).

\section{Proměny životního běhu mladých dospělých}

Od sedmdesátých let 20. století se v zahraniční literatuře začíná mluvit o prodlužování mládí a je popisována nová životní fáze nazývaná post-adolescence (Galland 1984; Richter 1994; du Bois-Reymond 1998; Maguire, Ball a MacRae 2001; Heath a Cleaver 2003). Představa nové fáze vkládané mezi mládí a dospělost v sobě zahrnuje předpoklad určité „normální“ dospělosti, kterou mladí lidé z nějakého důvodu částečně a dočasně odmítají. Odkládány jsou zejména tranzice charakteristické dlouhodobějším závazkem, jako je manželství a rodičovství. Změny v životním běhu nastávají s narůstající tendencí zůstávat delší dobu ve vzdělávacím procesu, s potřebou flexibility a zvyšování konkurenceschopnosti na pracovním trhu a také s možností volit a zkoušet nejrůznější způsoby seberealizace a konstrukce životního běhu (Plug, Zeijl a du Bois-Reymond 2003). Zvláštní význam je také přisuzován neformálním způsobům získávání zkušeností, např́íklad participací na vrstevnických skupinách, v zájmových organizacích nebo ve vedlejších zaměstnáních. Tato skutečnost způsobuje nejen stírání povinností formálně spojených s mládím (vzdělání) a dospělostí (práce), ale také rozrušování podstaty jednotlivých sociálních oblastí, například vzdělání jako učebního procesu a volného času jako sféry zábavy (Zeijl 2001; Plug, Zeijl a du Bois-Reymond 2003). Životní koncept je stále více závislý na individualizovaných plánech a rozhodnutích 
a dokonce i pohlaví, jeden z hlavních faktorů strukturace životního běhu, ztrácí svůj vliv (du Bois-Reymond 1998).

K vysvětlení nových způsobů života realizovaných současnými post-adolescenty je používán termín „volené biografie“ („choice biography“) (Beck 1992). Takto pojaté biografie neodkazují k neomezenosti volby, ale naopak označují napětí mezi možností/svobodou a legitimizací/nátlakem (du Bois-Reymond 1998). Ačkoliv (západní) společnosti nabízejí více možností výběru, (mladí) lidé jsou zároveň nuceni reflektovat tyto možnosti a ospravedlňovat svá rozhodnutí. Oddalování dříve běžných životních tranzic může být z tohoto pohledu vnímáno jako odmítnutí dlouhodobých závazků nebo také jako nutná př́prava předcházející důležitým životním rozhodnutím. Post-adolescenti nemohou být studováni jako homogenní skupina osob (Maguire, Ball a MacRae 2001), a z tohoto důvodu také není možné stanovovat věkové limity post-adolescence. Většinou je nicméně toto období zmiňováno v souvislosti s životním stylem dvacátníků a třicátníků (Heath a Cleaver 2004) a určováno na jedné straně legální hranicí dospělosti a na straně druhé průměrným věkem vstupu do manželské nebo rodičovské etapy. Někteří autoři spojují post-adolescenci spíš s nižším věkem - například Richter (1994) ji umist'uje přibližně mezi 18. a 28. rok věku - adolescence je podle něj fází teenagerů, post-adolescence fází dvacátníků. V roce 2000 přišel americký psycho$\log$ Arnett s teorií „vynořující se dospělosti“ jako nově se ustavující fáze mezi adolescencí a mladou dospělostí a klade ji do věkového rozmezí 18-25 let. Důvodem pro toto věkové vymezení nové fáze, kterou lze do jisté míry chápat jako obdobu post-adolescence, je její značná diverzita oproti předchozímu a nadcházejícímu životnímu období. S odkazem na jiné autory (Rindfuss 1991, Wallace 2000) považuje Arnett vynořující se dospělost za etapu velké demografické variability a nepředvídatelnosti - zatímco většina adolescentů do 17 . roku věku žije s rodiči, nemá děti a navštěvuje školu a většina dospělých okolo 30 . roku věku vstupuje do manželství a rodičovství, pro definici etapy mezi nimi nelze najít takto jednoznačně definované znaky. Jde o období experimentů a hledání vlastní identity v nejrůznějších životních oblastech (práce, bydlení, vztahů, životních postojů) (Arnett 2000).

Někteří autoři se vymezují vůči takto striktně vydělovaným a definovaným fázím životního běhu a kritizují „tezi prodlužujícího se mládí“, protože vychází z normativní definice dospělosti (Maguire, Ball a MacRae 2001; Blatterer 2007, 2010; Molgat a Vézina 2008). Představa „normální“ dospělosti, podle níž je dospělý jedinec definován určitými typickými charakteristikami, v sobě zahrnuje riziko nebezpečných a stigmatizujících interpretací. Na jednu stranu vnucuje představu stálosti a neměnnosti statusu dospělého a na druhou stranu odsuzuje jako deviantní nebo ,jiné“ ty, kteří tyto znaky nenaplňují (Maguire, Ball a MacRae 2001). Blatterer (2007) poukazuje na rozpor mezi novými způsoby a starými normami - touha mladých lidí po stabilitě je často v konfliktu s jejich náchylností $\mathrm{k}$ otevřenosti a mobilitě. Nejde však o deficit dospělého statusu, ale spíše o normativní změnu vyvolávající potřebu nové definice současné dospělosti. Životní praxe mladých dospělých je současně strukturálně oceňovaná i diskurzivně zneuznávaná, protože ve společnosti přetrvávají normativní ideály asociované s tradičním životním během a definicí dospělého jako „úplné osoby“.

Následující kapitoly reflektují rozhodování o mateřství jednak z pohledu měnící se struktury a významu životního běhu, jednak v kontextu proměn partnerských vztahů a očekávání, která jsou s nimi spojena. 


\section{Výzkum prvorodiček a bezdětných žen po třicítce}

Empirická část textu vychází z analýzy kvalitativního výzkumu, který proběhl v letech 2005-2008, s tematickým zaměřením na životní dráhy a reprodukční strategie žen starších třiceti let. Sběr a analýza dat korespondovaly s konstruktivistickou verzí zakotvené teorie (Charmaz 2006). Data byla sesbírána pomocí hloubkových, nestandardizovaných rozhovorů s celkem 35 ženami. V prvním prrípadě šlo o 20 matek, které porodily své první dítě po třicítce, ve druhém o 15 bezdětných ${ }^{3}$ žen stejného věku. ${ }^{4}$ Účastnice výzkumu byly kontaktovány $\mathrm{v}$ rámci sociálních sítí výzkumnice a následně technikou sněhové koule. Mezi konverzačními partnerkami převažují ženy s vyšším vzděláním (20 vysokoškolaček, 13 žen se středoškolským vzděláním s maturitou a 2 vyučené ženy), což je dáno možnostmi výzkumnice a jejích sociálních sítí a menší ochotou žen s nižším vzděláním k účasti na těchto typech výzkumů.

Rozhovory byly se souhlasem konverzačních partnerek ${ }^{5}$ nahrány na diktafon, doslovně přepsány a analyzovány s pomocí programu Atlas.ti (délka rozhovorů se pohybovala v rozmezí od 40 minut do dvou hodin). Analýza dat probíhala ve shodě s pravidly zakotvené teorie, pomocí metody konstantního srovnávání, identifikací kategorií - jejich vlastností a dimenzí - a trojím typem kódování (otevřeným, axiálním a selektivním), s cílem uspořádat kódy do širších souborů a rodin (Strauss a Corbin 1999).

Konverzační partnerky $\mathrm{v}$ rozhovorech retrospektivně hodnotily jednak minulé partnerské zkušenosti a průběh života až do rozhodnutí o mateřství nebo do doby uskutečnění rozhovoru a jednak reflektovaly svůj postoj k mateřství od doby svého dospívání. Absence partnerského vztahu byla často explicitně zmiňována jako hlavní důvod odkládání mateřství. Nicméně, jak bude dále v textu ukázáno, skutečný vliv partnerských vztahů na rozhodování o mateřství byl málokdy takto přímý.

\section{Post-adolescence a proměna kritérií výběru partnera}

Jsem obecně pomalejší, tak jsem asi propásla nějakou tu př́ležitost...

V souvislosti s konceptem ,volené biografie“ se mluví o stále častěji pozorovaném vlivu „jojo efektu“ na podobu životního běhu (yo-yo-ization of life course), kdy v průběhu celé

3 Bezdětnost nebo mateřství v tomto věku přitom nesměly být zapř́íčiněny biologickými bariérami plodnosti (neplodností, dlouhodobou nemocí atp.).

4 Prožitek bezdětnosti nebo mateřství mohl ovlivnit způsob výpovědí žen, a to především $\mathrm{v}$ případě retrospektivního pohledu matek: vyprávění aktérek nelze $\mathrm{v}$ tomto př́ípadě chápat jako reflexi toho, co se skutečně odehrálo, ale jako způsob, jakým svoji minulost aktuálně konstruují. Zpětná rekonstrukce událostí a minulých zkušeností je ovlivněna situací, ve které se žena právě nachází (Sandelowski, Holditch-Davis a Harris 1990). Zatímco nechtěně bezdětné ženy se ocitají tváŕí v tvář zvyšujícímu se věku a mateřské touze a tuto situaci jsou nuceny aktuálně řešit, jiné ženy, které mohly projít podobným obdobím v minulosti, na něj vzpomínají už jen z pozice aktuálně prožívaného mateřství. I navzdory této skutečnosti je na obě skupiny žen ve výzkumu nahlíženo jako na celek, což je umožněno podobností jejich životních príběhů.

5 Účastnice výzkumu nejsou v textu uvedeny pod svými skutečnými jmény. 
biografie dochází ke kombinaci různých rolí, tedy i těch, které se dříve vázaly jen $\mathrm{k}$ určité životní fázi (du Bois-Reymond 1998, Elchardus a Smits 2006, Vinken 2007). Elchardus a Smits (2006) zmiňují např́klad studenty, kteří na několik let přeruší studium kvůli práci; pracující, kteří se naopak dočasně vrací ke studiu; důchodce, kteří se vrací do pracovního procesu; muže a ženy, kteří se žení či vdávají ještě před dokončením studia a další.

$\mathrm{V}$ biografiích několika konverzačních partnerek byl tento efekt pozorovatelný v jejich návratu do vzdělávacího procesu v pozdějším věku - okolo třiceti let -, kdy již byly delší dobu ekonomicky nezávislé. Nicméně mateřská role je v úvahách žen zobrazována poněkud odlišně - jako těžko slučitelná s jinými rolemi. Rozlišováno je období nejrůznějších zkušeností, nesouvisejících s mateřstvím, a období mateřství, kdy je nutné předchozí role opustit a v prvních letech dítěte se věnovat především jemu. Zatímco takové tranzice, jako je odchod od rodičů, dokončení vzdělání nebo zaměstnání na plný úvazek, mohou být v tomto období zvratitelné, tranzice k mateřství nastoluje nutnost stabilnějšího životního způsobu. Toto pojetí zcela odpovídá představě nové životní fáze předcházející rodičovství a charakteristické nestabilitou, flexibilitou, nezávazností a absencí manželství a rodičovství jako dříve důležitých znaků dospělosti.

Mnoho žen ve výzkumu prošlo obdobím, kdy zakusily partnerské vztahy, které nebyly chápány jako perspektivní pro rodičovství. Nezdá se, že by takové vztahy záměrně vyhledávaly; jejich charakter pravděpodobně vyplývá z faktu, že rodičovství v této životní fázi není prioritou, a nestává se proto ani důležitým kritériem výběru partnera. Pozdější vstup do mateřské fáze nebo další odkládání mateřství vysvětlovaly některé z nich absencí partnerského vztahu. Přestože neexistence partnera nebo neexistence partnera vhodného pro rodičovství je ženami často předkládána jako nechtěná shoda okolností, je zároveň zřejmé, že v určitém období není hledání takového vztahu prvořadé:

Až vlastně do těch třiceti let - neměla jsem partnera, se kterým bych dítě chtěla mít. Přemýšlela jsem nad dítětem, ale ne nějak intenzivně, protože spíš prvořadé bylo najít toho partnera, ale to mně zase začalo docházet až kolem těch 30 , až jsem si splnila to, co jsem chtěla realizovat já sama, svoje sny a představy, čili vlastně jsem studovala vysokou školu, pak jsem jela do ciziny, sháněla jsem si tam byt, sehnala jsem dobré místo, takže to jsem si uspokojila do té třicítky, a pak jsem začala přemýšlet o dítěti. [...] po té třicítce jsem už začala opouštět ten svůj minulý vztah a už jsem začala hledat něco jiného. [...] Měla jsem pocit, že na minulého partnera není spolehnutí, že mě v některých věcech třeba neříká úplně pravdu, prostě když jsem si ho představila v roli otce, tak mi tam něco nesedělo.

(Dana, vysokoškolské vzdělání, 35 let při narození prvního dítěte)

Velmi podobně uvažuje i Dagmar v odpovědi na otázku:

Výzkumnice: Takže to [absence partnera] byl ten důvod odkládání mateřství?

Konverzační partnerka: To byl ten důvod. [...] Takhle. Já bych asi nechtěla moc brzo mít dítě. Prostě do třicítky, to bych možná ani nechtěla, i kdybych toho partnera měla, nevím, to je kdyby... přece jen šlo o takový vztahy, ne moc partnerský, spíš takový milenecký, bud' ani jeden nebyl přesvědčen, nebo to rychle skončilo anebo... 
Výzkumnice: A v čem byl problém, že jste nemohla najít toho správnýho muže?

Konverzační partnerka: Já jsem to nepovažovala za problém [kurzíva výzkumnice]. Asi moc velká vybíravost, možná člověk taky neznal dobře sám sebe...

(Dagmar, vysokoškolské vzdělání, 34 let při narození prvního dítěte)

Jak ukazují obě citace, hranice post-adolescence jsou dány jednak pocitem naplnění v oblasti seberealizace či ukončení procesu hledání sebe sama a své identity, na druhou stranu tyto pocity často přicházejí spolu s normativně danými věkovými hranicemi mateřství. Vnímání věkových limitů mateřství podněcuje některé ženy k rychlému a racionálně definovanému jednání ve věcech vztahů. Snaha rychle přjít z jedné fáze do druhé vyžaduje „oběti“ v podobě slevení z „př́liš romantických představ o partnerském vztahu“ (z citace Dany). Dana volí seznámení s mužem přes inzerát, i když to nepovažuje za ideální způsob seznámení, Dagmar rezignuje na př́liš ideální představy o partnerovi a stačí jí, že mezi ní a partnerem není „zásadnější problém“, Anna (středoškolské vzdělání, 34 let při narození prvního dítěte) se i přes pochyby o partnerovi a chybějící pocit zamilovanosti rozhoduje pro manželství z důvodu pozitivního postoje partnera k rodinnému životu. Mateřství se stává hlavním projektem a náplní životní fáze „,po trricítce“ - jsou mu podřízeny představy o partnerském vztahu. Od vztahů spojovaných již explicitně s rodičovstvím se často neočekává, že budou naplňující samy o sobě, např́íklad právě ve smyslu prožívání zamilovanosti, ale že vytvoří dobrý základ budoucí rodiny.

Přestože z těchto výpovědí jasně vyplývá vědomí proměny kritérií při výběru partnera, konkrétní vlastnosti muže vhodného k založení rodiny většinou ženy př́liš jasně pojmenovat nedokázaly. $\mathrm{V}$ odpovědích na prrímou otázku, jaký by takový muž měl být, se někdy objevovaly vlastnosti jako spolehlivost, jistota, zodpovědnost, opora, tedy takové, které můžeme asociovat $\mathrm{s}$ obecnějším důrazem na trvalost vztahu. V popisu partnerských vztahů z období, kdy mateřství ještě není bezprostředně plánováno, tato charakteristika naopak chybí. Podle mnoha výpovědí lze bezdětné období definovat jako prostor pro hledání sebe sama, svých životních priorit a své identity. S tím zřejmě souvisí i pojetí partnerských vztahů prožívaných v této etapě jako zdroje posílení identity nebo sebevědomí obecně:

...v té době to byli většinou chlapi, kteří jsou zábavní, kteří vám nějak umí dát zažít pocit, že jste výjimečná, jedinečná, ti si pak můžou dovolit těch ženskejch víc nebo jsou schopný jich víc získat. Takže do jistý doby pro mě byla důležitější kvalita, jako ta zábavnost, než spolehlivost a věci, kterých si dnes cením víc. Jako je pro mě důležitý ted', aby ten chlap byl spolehlivej, nelhal mi a prostě to, co mi dřív nebylo sice ukradený, ale nebylo to ani nejdůležitější. Je to ted' logicky nějak jinak.

(Soňa, středoškolské vzdělání, 38 let, bezdětná)

Oni byli... jak se říká, že si vybíráte špatné muže, takže jednak byli třeba ženatí, což nebylo nic, čím bych se pyšnila nebo za co bych se ted'ka chválila, bylo to spíš proto, aby to člověku dodalo sebevědomí, moc o nic jiného nešlo, abych tak řekla... nevím...

(Markéta, vysokoškolské vzdělání, 38 let při narození prvního dítěte) 
V mladé dospělosti i později lidé otevřeně provozují formy sexuálních vztahů, které byly dříve nepř́ípustné, jako je seriálová monogamie, kohabitace, homosexuální svazky (Gross 2005). Pro některé ženy ve výzkumu nebylo problematické zmínit i vztahy se ženatými milenci. Důležitým aspektem těchto vztahů je, že často nemají dlouhodobou perspektivu a toto očekávání do nich ani není vkládáno. Zpětně jsou však vnímány ambivalentně. $\mathrm{Na}$ jednu stranu mají v určitém období svůj účel (,zvyšují sebevědomí), na druhou stranu však mohou být hodnoceny negativně - jako něco, čím by se člověk nerad ,pyšnil“, nebo jako skutečnost odkazující na nedospělost („,dětinskost“; dobu, kdy „člověk ještě neznal sám sebe“). Pocit určitého stigmatu, které z jejich existence může vyplývat, byl vnímán především ženami, které později odkládaly mateřství z důvodu chybějícího partnerského vztahu. Čas strávený s neperspektivními (doslova „nespolehlivými“) muži mohl být nepřímo pojímán jako ztracený a podílející se na pozdějších partnerských neúspěších. Jak podotýkají Sandfield a Percy (2003), zejména v pozdějším věku interpretují ženy „singlovstvi““ (a s tím často související bezdětnost) jako své vlastní selhání spíše než volbu. V této souvislosti popsali Sharp a Ganong (2007) na př́kladu vysokoškolsky vzdělaných žen bez partnera (28-34 let) jejich vědomí „ztracené (partnerské, manželské) tranzice“. Tímto způsobem vyjadřovaly ženy nedobrovolnost svého singlovského statusu, která je umocněna pocitem marginalizace sebe sama ve společnosti stále silně orientované na partnerský život a rodičovství. K podobným výsledkům dospěly i jiné studie zaměřené na samostatně žijící ženy v podobném věku (Chandler 1991, Gordon 1994, Trimberger 2005).

Prosazující se životní styl spjatý s bezdětným obdobím s sebou přináší nové normy a hodnoty, které jsou protikladné k normám tradičním, jež by měly být naplněny v období následujícím. Ženy jsou nuceny vyrovnávat se s tlakem velmi protichůdných požadavků. Mít dítě v mladším věku je již vnímáno jako nezodpovědnost, protože člověk není považován za dostatečně připraveného na rodičovství (Hašková a Zamykalová 2007, Bartošová a Slepičková 2009). Zároveň to však neznamená, že by měl být v tomto bezdětném období bez partnera nebo neměl mít žádné sexuální zkušenosti. Ty jsou naopak vmímány jako hodnotné („zvyšující sebevědomi““). ${ }^{6} \mathrm{~V}$ období, kdy je již zvažováno rodičovství, by měla být naopak prokázána schopnost utvářet stabilní a dlouhodobý vztah. Ideál rodiny spojené

6 I přes nesporný nárůst počtu lidí žijících jako singles je převládající hodnocení lidí, kteří nedosahují sexuálního partnerství, spíše negativní. Existuje velmi málo pozitivních reprezentací nepárového způsobu života, které by byly možným zdrojem vytvoření pozitivní „singlovské“ identity (Budgeon 2008). Reynolds a Wetherell (2003) provedly rozhovory se ženami ve věku 30-60 let, které někdy ve svém životě žily delší dobu samy a neměly partnera. Autorky mimo jiné zjišt'ovaly, jakými významy zkoumané ženy naplňují sociální kategorii „singles“ a jaký si myslí, že je její převládající obraz ve společnosti. $Z$ rozhovorů vyplynulo, že singlovství je na jednu stranu popisováno v termínech nezávislosti, volby, seberealizace a úspěchu. Zároveň však zahrnovalo výrazné negativní konotace, jako například osobní nedostatečnost a zkušenost sociální exkluze. Na základě těchto protikladných významů se podle autorek stává kategorie „,single ženy“ prekérní a pro ženy je obtížné se se singlovskou zkušeností pozitivně identifikovat. Například přihlášení se k pozitivnímu obrazu single znesnadňovalo ženám možnost připustit sobě i druhým touhu po partnerství, protože hrozilo, že bude spojena s pocity nedostatečnosti a zoufalstvím. 
i s dlouhodobým partnerským závazkem není zcela opuštěn, ale pouze odsunut do pozdější doby, ohraničené věkovými normami mateřství.

Beck (1992) mluví o subjektivizaci a individualizaci společensky a institucionálně produkovaných rizik a rozporů. Pro jednotlivce nejsou institucionální situace, jimiž je determinován, už jen vnějšími událostmi a okolnostmi, ale také důsledky jeho vlastních rozhodnutí. V tomto kontextu zmiňuje Morgan (1999) asociaci mezi sociální reprezentací osobního života jako privatizované intimity a ustavováním psychologických expertů jako specialistů ve věcech partnerských vztahů a jejich napravování. Ženy, reflexivně utvářející svoji biografii v podmínkách nově se ustavujících norem a institucionalizovaných životních stylů, proto mohou klást vinu samy sobě v př́ípadě, že některou z protichůdných norem nenaplňují. Konverzační partnerka Soňa, citovaná v úvodu kapitoly, vysvětluje svoji nechtěnou bezdětnost vlastní „pomalosti““ - neschopností včas rozpoznat, kdy je nutné opustit nezávazný životní styl a zaměřit se na hledání stálého partnera a budování rodiny. Zdroj nápravy neúspěšného partnerského života může být spatřován v zásahu psychologů a jejich interpretačního rámce, jak ukázal prŕíklad konverzačních partnerek Markéty a Evelíny, které se kvůli neschopnosti najít (vhodného) partnera obrátily na tuto formu pomoci.

V dalších kapitolách se pokusím ukázat, že problémy v partnerských vztazích nebo při hledání partnera nemusí být důsledkem neschopnosti nebo specifických povahových vlastností žen, jak se některé z nich domnívají. Zdroj partnerských potíží je třeba vidět spíše jako následek - pro ženy „schizofrenní“ - situace, kdy je jejich tradiční životní dráha systematicky narušována, přestože povinnosti a normy s ní spojené ve společnosti stále přetrvávají a jsou od nich očekávány.

\section{Genderová dimenze společného soužití a zvyk na samostatné bydlení}

Chlap sám je prostě nemožnej, málo kterej umí ovládat pračku, na nádobí nesáhne...

(Doubravka)

Zvyšující se participace žen na pracovním trhu nevede $\mathrm{k}$ velké změně dělby práce v domácnosti mezi partnery (Coltrane 2000, Baxter 2002) a zvyšující se genderová rovnost ve veřejné sféře nepřináší automaticky rovnost i v oblasti soukromí (McDonald 2000a, b). Spíše než se zapojením muže do domácích prací je nástup žen na pracovní trh asociován se snižujícím se časem, který věnují domácím pracím, nebo $\mathrm{s}$ jejich dvojitou zátěží v placené a neplacené práci (Western a Baxter 2001, Baxter 2002). V české společnosti navzdory egalitárním názorům přetrvává tradiční rozdělení genderových rolí, kdy je žena hlavní pečovatelkou o rodinu a domácnost, přestože je zároveň po většinu své pracovní dráhy zároveň zaměstnána na celý úvazek (Ettlerová a kol. 2006, Křížková 2007). I přes časté přetrvávání tradičního modelu dělby rolí mezi partnery se mění očekávání neekonomického přínosu muže a ženy v jejich rodinách, zejména s ohledem na rozdělení domácích prací a péče o děti, a toto očekávání se stává důležitým faktorem změn v partnerství i rodičovství. Strukturální překážky a př́ležitosti utváří reprodukční možnosti jedinců (Simpson 2010).

Existence prodlužujícího se bezdětného období v životní dráze vede často $\mathrm{k}$ realizaci různorodých forem partnerských vztahů. Podle Arnettovy teorie „vynořující se dospělosti“ 
jde o období hledání vlastní identity mimo jiné i v oblasti lásky a vztahů. Mladí lidé se $\mathrm{v}$ této době vymaňují z vlivu a kontroly rodičů a zároveň ještě nejsou ve věku, kdy by byli vystaveni normativnímu tlaku ke vstupu do manželství nebo rodičovství. Prožité zkušenosti nicméně nemusí být zpětně hodnoceny pozitivně, naopak mohou vést $\mathrm{k}$ pocitům zklamání a ztrátě iluzí (Arnett 2000).

Konverzační partnerky zakoušely v této životní etapě různé typy vztahů: některé prošly opakovanými nesezdanými soužitími, jiné zůstávaly delší dobu singles, přestože zažívaly kratší, převážně sexuální vztahy, jiné měly dlouhodobého partnera. Nabývání různých zkušeností z partnerských vztahů a narůstající samostatnost (zejména ve sféře bydlení a práce) mohly vést u některých $\mathrm{z}$ nich $\mathrm{k}$ postupnému oslabování schopnosti společného partnerského soužití a k blokování přechodu z nezávislého, individualizovaného životního stylu k rodinnému. Zdá se, že významnou roli v tomto procesu hraje přesvědčení žen o neschopnosti mužů podílet se spolu s nimi na práci v domácnosti a na péči o děti. Toto přesvědčení vzniká jednak na základě zkušeností z původní rodiny, z pozorování okolí a zejména z vlastních partnerských vztahů. Některé ženy označily původní rodinu (at’ už svoji, nebo partnera) za jeden z hlavních zdrojů prístupu mužů $\mathrm{k}$ domácím pracím:

...z mý vlastní osobní zkušenosti, tak si myslím, že to dělaj matky a sestry, protože kluci, který mají ségry a mámy, který se o ně starají, tak ty neumějí fakt nic, a to je můj manžel prostě [smích]...

(Sylvie, vysokoškolské vzdělání, 31 let při narození prvního dítěte)

Nejde však pouze o neschopnost práce v domácnosti, ale i o celkovou pasivitu a závislost mužů na ženách v širším kontextu rodiny a rodinných vztahů, ke kterým jsou v průběhu dětství a dospívání, a někdy i ve vlastních partnerských vztazích, ženami vedeni:

...oni [muži] jsou zpohodlněni tím, že, to vidím i na svém nejstarším bratrovi, že byl tak zvyklý, že se mu manželka a maminka - vždycky se o něho staraly, aby měl všechno nachystané, a v prípadě, kdy mu ted' po letech rodinný život ztroskotává, tak si myslím, že se neumí postavit na vlastní nohy, pořád ho musí někdo dokopávat.

(Marie, vyšší odborné vzdělání, 33 let, bezdětná)

Dívky jsou podle konverzačních partnerek vychovávány k větší samostatnosti ve sfére domácnosti než chlapci, což se může projevit v dospělosti - ve schopnosti žen starat se o (samostatnou) domácnost a být tímto způsobem nezávislé:

U žen je mnohem snazší zvyknout si na nezávislost, protože ženy jsou k tomu jednak vychovaný, asi je to výchovou, že jsou vychovaný k tomu, starat se o domácnost. Chlap sám je prostě nemožnej, málo kterej umí ovládat pračku, na nádobí nesáhne...

(Doubravka, středoškolské vzdělání, 34 let, bezdětná)

Touha po samostatném bydlení a její realizace byla $v$ určitém období pro mnohé konverzační partnerky zásadní. Podle výpovědí žen symbolizuje dosažení samostatného bydlení (nejlépe v podobě vlastního bytu) nezávislost (na rodičích i partnerovi), ale zároveň označuje schopnost nebo vyjadřuje nutnost zajistit tímto způsobem budoucí život s dítětem. 
Z předešlého i následujícího úryvku je zároveň zřejmé, že ženy se s odkazem na svoji schopnost žít samy vymezují vůči mužům, kteří podle nich častěji podléhají nějaké formě závislosti a péče:

No a taky hlavně, ten můj bratr, o tři roky starší, se nechal živit od těch rodičů, já nevím do kolika, do třiceti bezmála, a mně se to nelíbilo, vůbec, chtěla jsem mít svoje peníze a nebýt na někom závislá.

(Veronika, středoškolské vzdělání, 31 let, bezdětná)

S těmito úvahami žen zajímavě korespondují výsledky kvantitativního výzkumu mladých lidí (25-44 let) žijících samostatně, které ukázaly, že muži hodnotí tento způsob bydlení spíše jako shodu okolností, způsobenou například rozpadem minulého vztahu, a naopak samostatně žijícími ženami je častěji vysvětlován jako aktivní volba směřující k ekonomické nezávislosti a autonomii (Jamieson, Simpson a Wasoff 2009). Lze se domnívat, že v ženách je $\mathrm{v}$ období socializace $\mathrm{v}$ dospívání mnohem silněji budován vztah $\mathrm{k}$ domácímu prostoru jako ženami chráněné a kontrolované sféry. Potřeba založit si vlastní domácnost proto pro ně může být znakem emancipace a dospělosti více než pro muže. Zatímco v tradičně uspořádané rodině byla domácnost hájemstvím ženy a muž nebyl k některým činnostem vůbec připouštěn, dnes ženy očekávají společnou starost partnerů o tuto sféru. Jak ukázal kvalitativní výzkum Tomáška (2006), přesvědčení o neschopnosti mužů splnit toto očekávání může však vést k ochraně domácnosti před mužskými „,narušiteli“ a k odmítání společného soužití partnerů.

Samostatné bydlení a cesta $\mathrm{k}$ němu, jak je patrné z výše zmíněných motivací, představuje pro ženy symbol jejich dvojího úkolu. Na jednu stranu předpokládá ekonomickou zabezpečenost ženy a její dobrou pozici na pracovním trhu, jako znaky dříve související s mužskou živitelskou rolí. Zajištění bydlení však na druhou stranu znamená i nutný krok $\mathrm{k}$ výkonu budoucí mateřské role - zabezpečení prostoru pro život s dítětem. Hypoteticky lze uvažovat nad tím, že ženy, vedeny zkušenostmi z dětství, ale i ze svých vlastních partnerských vztahů, berou za své nároky tradičně rozložené na bedra obou pohlaví. Osvojení a zvládnutí dříve výhradně mužské role a připravenost na mateřskou roli, a zároveň přesvědčení o neschopnosti mužů chovat se podobným způsobem nebo dokonce nenaplňovat ani nároky mužské tradiční role, mohou vést $\mathrm{k}$ výrazným problémům $\mathrm{v}$ partnerství nebo při hledání partnera. Patrně i z důvodů touhy po úplné rodině, jak bude ukázáno v další kapitole, není však tato možnost v rozhovorech vyjadřována explicitně. Patrná však může být ve lpění na dosavadním, samostatném životě, i když nezmiňovaném s př́mými genderovými konotacemi. Upevňující se nezávislost žen, at' už prostřednictvím úspěchu v zaměstnání nebo právě v zajištění vlastního bydlení, může mít nezamýšlený důsledek v podobě snižující se schopnosti kompromisu v soužití s partnerem $\mathrm{v}$ tradičně uspořádané domácnosti. A to zejména u žen, které delší dobu žily samy. Na základě svých výzkumů konstatují Jamieson, Simpson a Wasoff (2009), že samostatně žijící ženy se s postupem času učí cenit si tohoto svého statusu a mohou jej začít vnímat jako pevnou součást své identity. 
Ve vyprávění konverzační partnerky Veroniky se odráží rozporuplnost provázející její uvažování o společném životě s partnerem a o mateřství. ${ }^{7}$ Rodinný život sice zmiňuje jako ideál, její žité zkušenosti se však s postupujícím věkem stále rychleji vzdaluje. Neschopnost najít partnera je spojena se zakotveností v ,singlovském“ zpo̊sobu života:

Já myslím, že asi mám docela velký nároky. A myslím si, že je to i tím, že jsem ted' už docela samostatná nebo ukotvená v sobě, že už tak jako nepřistoupím na všechno. A tím, jak si žiju tím svým, docela pohodlným způsobem, tak si myslím, že je to rok od roku těžší [najít si partnera].

(Veronika, středoškolské vzdělání, 31 let, bezdětná)

Podle mnoha výzkumů je součástí budoucích plánů mladých singles nebo osob žijících samostatně rodina a partnerské spolu-soužití. Jejich životní styl a preference však zároveň naznačují postupné oslabování schopnosti společného soužití s partnerem a tendenci k prodlužování nezávislého způsobu života. Lidé definují a oceňují výhody samostatného bydlení, které mohou výhodám společného soužití konkurovat (Molgat a Vézina 2008; Jamieson, Simpson a Wasoff 2009; Tomášek 2006). V príípadě žen může být výraznou hodnotou možnost vyhnout se genderově nerovnoměrnému rozložení rolí v domácnosti.

\section{Čistý vztah - vztah bez dětí}

...potřebuju mít možnost, že když nebudu chtít v nějaké situaci zůstat, tak se vždycky můžu sbalit a odejít. Nemožnost odejít mě děsí úplně nejvíc, nemám ráda věci, ze kterých se nedá odejít.

(Zdeňka)

Explicitně označily preferenci samostatného bydlení z důvodů odmítnutí nerovného rozložení rolí mezi partnery pouze ženy, které i do budoucna volí spíše bezdětnost. Ostatní ženy, přestože si byly této skutečnosti vědomy nebo se stávala zdrojem konfliktů v jejich partnerských vztazích, ji nepovažovaly za nepřekonatelný problém společného soužití. Volba mateřství zahrnuje ve vyprávění žen vždy také volbu společného soužití s partnerem a dětmi, ačkoliv za cenu určitých kompromisů. Pokud muž naplňuje tradiční roli živitele, jsou ženy ochotny přijmout i svoji roli primární pečovatelky o dítě a domácnost.

Budgeon (2008) ve vyprávění žen-singles identifikovala „strategické distancování se“ od partnerského ideálu jako způsob, jak se vypořádat s rozporem mezi osobní a sociální identitou. Singlovství jako společensky nepř́liš kladně hodnocený stav bylo ženami definováno v termínech př́ležitostí, které mohou být v partnerském vztahu ztraceny. Vyhraňování se vůči párovému životu je strategií, jak se vyhnout marginalizovanému statusu singles. Tento postoj je zároveň zdrojem ambivalence, kterou se ženy snaží usmírit přehodnocováním pojetí a struktury partnerských vztahů: I přes proklamované nevýhody partnerského vztahu nevylučují budoucí vstup do vztahu, ale pouze za určitých podmínek (,mít vztah ano, ale..."). Právě výpověd’ konverzační partnerky Veroniky byla př́íznačná neustálou oscilací mezi zdůrazňováním výhod singlovství (a bezdětnosti) oproti párovému životu (a rodině), a zároveň vědomím společností vnucovaného a jí částečně prijímaného párového a rodinného ideálu. 
...to je právě úplně hrozný, můj manžel je úplný lempl, nedělá nic, a to vždycky byla, to je vlastně jediná věc, kdy my máme spor. [...] To je štěstí, že nás aspoň uživí, protože jinak...

(Sylvie, vysokoškolské vzdělání, 31 let při narození prvního dítěte)

Když však partner ,selhává“ i v rolích, které jsou mu tradičně připsány (v následující citaci v podobě ekonomického zajištění rodiny), stává se tato skutečnost zdrojem dlouhotrvajících konfliktů a nespokojenosti ženy ve vztahu:

...chlapi jsou uskuhraní, já jsem ř́íkala tomu mému, ty se musíš naučit být tvrdší, zvykej si, že bude ještě hưr̆, budou horší problémy. A je to smutné, on teprve se mnou zažívá, co to je normální život, co to jsou běžné starosti, které šly mimo něho. [...] Jeho máti je mu pořád s prominutím za zadkem. Tak to jsme se strašně hádali, nesnášela jsem to, že mu je tolik a ona ho pořád kontroluje jak malého kluka... Pak jsem zjistila proč, protože měla kontrolu nad vším, co dělal, bohužel i nad penězi, protože on neumí šetřit, takže mu vždycky po částech dávala peníze...

(Sandra, vyučená, 34 let při narození prvního dítěte)

Na prríkladu žen volících i do budoucna spíše bezdětnost je patrné, že tradiční pojetí partnerského vztahu, např́iklad v podobě společného soužití partnerů, může být snadněji opuštěno spolu s představou mateřství. Konverzační partnerka Zdeňka, která se s přibývajícím věkem upevňovala ve svém přesvědčení nemít děti, vystihla esenci čistého vztahu, popsaného Giddensem (1992), ve své odpovědi na otázku po smyslu jejího vztahu s partnerem, jenž byl praktikován ve formě ,spolu, ale odděleně““:8

Je to člověk, se kterým můžu podnikat věci, nehádáme se, pořád se na sebe těšíme tím, že spolu nebydlíme, furt je to takový hezký a zamilovaný. Děláme spoustu věcí, který nás baví a který můžeme dělat společně, můžeme spolu mluvit, protože on se hodně orientuje v umění, v kultuře, což je moc př́ijemný, má dobrý názory, máme stejný smysl pro humor, líbí se nám stejný filmy, je to takový i parták zkrátka, chodíme na výlety. Jako hodně upřímně: je to takový hodně dobrý přátelství kořeněný sexem. Jako že my nejsme partneři, nemáme takovej ten partnerskej život, nesdílíme spolu žádný velký cíle a nejvnitřnější pocity, ale je nám spolu dobře a myslím si, že ten vztah může vydržet poměrně dlouho, pokud prostě jednomu z nás tohle přestane vyhovovat.

(Zdeňka, středoškolské vzdělání, 31 let, bezdětná)

V Giddensově pojetí vyjadřuje čistý vztah (pure relationship) podobu intimních vztahů v moderní společnosti. Takový vztah není podmíněn ani ekonomickými, ani sociálními okolnostmi, je upevňován skrze volbu a vzájemnost spíše než rodinným závazkem, je postaven na svobodě jednotlivce, umožňuje vznik prostoru pro vytváření a rozvoj sama sebe a z jeho podstaty vyplývá, že může být ukončen ve chvíli, kdy přestane jednomu ze zúčastněných jedinců vyhovovat.

8 Citace $\mathrm{z}$ rozhovoru s touto konverzační partnerkou je použita i v záhlaví kapitoly. Zdeňka během svého vyprávění opakovaně zdůrazňovala, že dlouhodobé závazky, jako je manželství a mateřství, odmítá, především z důvodu jejich velké závaznosti a nemožnosti je jednoduše ukončit, pokud člověku přstanou vyhovovat. 
Ostatní dvě konverzační partnerky, které necítily potřebu mít dítě a tento stav považovaly za více méně stabilní, prožívaly podobně alternativní vztahy - vztah se ženatým milencem a př́ležitostné sexuální vztahy. Zatímco jiné ženy hodnotily podobné formy vztahů jako dočasné, spojené pouze s určitým životním obdobím a fungující jako náhražka dlouhodobého perspektivního vztahu, partnerské vztahy popsané těmito konverzačními partnerkami jsou přijímány jako chtěné a preferované před jinými formami vztahů (kohabitací nebo manželstvím). Zdá se, že hlavní výhoda těchto různých typů soužití je zachování samostatného bydlení. V prŕpadě Doubravky šlo o vztah se ženatým milencem, který ve smyslu emocionálního uspokojení a spolehnutí se na partnera hodnotila jako perspektivní, o rozvod svého partnera a změnu jejich vztahu v jeho důsledku neusilovala. Minulá zkušenost ze společného soužití s partnerem ji upevnila $\mathrm{v}$ přesvědčení samostatného způsobu bydlení:

Žila jsem s jedním přítelem, ale nevyhovovalo mně to, protože si ze mě dělal služku. On to bral dost extrémně, byl to takový tyran, ale zároveň myslím, že zábavný, takže to bylo hodně těžký nějak vyřešit. Nakonec jsem od něj tedy odešla, ale nevzbudilo to ve mně touhy s někým sdílet domácnost.

(Doubravka, středoškolské vzdělání, 34 let, bezdětná)

Konverzační partnerka Brigita se rozešla s dlouholetým prrítelem, se kterým sdílela domácnost poté, co odmítla jeho prání založit společně rodinu. Další partnerský vztah a soužití s partnerem zavrhovala a dávala přednost krátkým sexuálním známostem. Společné soužití s partnerem a rodinný život podle ní předpokládá řadu kompromisů (např́íklad právě nevyváženou dělbu prací v domácnosti), které dřive také činila, ale dnes už by jich nebyla schopna. Na otázku, zdali je pevně rozhodnutá nemít děti, odpověděla:

Pořád, pořád no. To už je tak, já už si tak žiju po svém, mám pocit, že děcko by mě to totálně narušilo. Já přijdu, dám kočkám jídlo, uklidím po nich a dělám, co potřebuju. Když je víkend, tak si ř́ikám, že někam pojedu nebo budu doma. Někdo přijde na návštěvu, já přijdu k někomu na návštěvu a žiju si tak po svým. A ještě když máte děcko, tak máte i partnera, je to lepší, protože myslím, že svobodná matka, to je za trest, a už se tomu musíte přizpůsobovat, dělat kompromisy, což je normální, protože jinak by se ti lidi pozabíjeli, ale to už já zase nejsem ochotna dělat.

(Brigita, vysokoškolské vzdělání, 37 let, bezdětná)

Volba bezdětnosti byla u těchto žen podmíněna souborem nejrůznějších faktorů. Preference samostatného bydlení, odmítání nerovného rozložení genderových rolí v domácnosti a zvyk na individuální životní styl však jejich volbu posiloval. Partnerské a mateřské preference žen však nefungují jednoduše jako př́čina jednoho a následek druhého, ale ovlivňují se obousměrně. Zkušenosti z genderově nerovných vztahů mohou upevňovat rozhodnutí o bezdětnosti. Odmítnutí mateřství pak osvobozuje od nutnosti kompromisů mezi partnery a otevírá prostor vztahům, které tyto kompromisy nevyžadují, ale zároveň ze své podstaty posilují perspektivu bezdětnosti.

Představu transformace intimity směrem k čistému vztahu, který je podmíněn rovností mezi mužem a ženou, systematicky kritizuje Jamieson (1999). Přestože jedinci přistupují k partnerským vztahům s očekáváním rovnosti, ve skutečném životě, zejména v soužití páru 
v jedné domácnosti, koexistuje intimita spolu s nerovností. Sdílení společné domácnosti, starost o ni a zejména rodičovství jsou zrrídka genderově neutrálními aktivitami, často naopak podněcují nerovnosti, např́klad v dělbě práce a trávení volného času. Bezdětný život naopak umožňuje lidem volit takové formy vztahů nebo rozdělení genderových rolí, které lépe odpovídá individualizovaným potřebám současné společnosti (Beck a Beck-Gernsheim 1995, Bauman 2002, Giddens 1992).

\section{Závěr}

Rozhodování o rodičovství se v současné době, kdy se mění věkové normy vztahující se k jeho časování a kdy jsou dlouhodobé závazky odkládány do pozdějšího věku, stává dlouhodobějším a komplexnějším procesem než dřive. Z pohledu převažujících kulturních reprezentací však je paradoxně ten správný moment pro zahájení mateřství poměrně úzce vymezen. $\mathrm{Z}$ hlediska různých mateřských norem musí ženy vhodný čas k mateřství zvažovat ve vztahu ke správnému věku přípustnému pro mateřství a vzhledem ke správnému momentu v životním běhu, tzn. v období perspektivní zaměstnanecké pozice, v manželském (partnerském) svazku, ve správné chvíli z hlediska dlouhodobých pracovních plánů, ve stavu materiálního a finančního zabezpečení atd. (Berryman 1991, Woollett a Boyle 2000, Sevón 2005).

Předchozí text je shrnutím části výsledků kvalitativního výzkumu zaměřeného na rozhodování o mateřství ve skupině žen, které porodily své dítě po třicítce, nebo ve stejném věku zůstávají bezdětné. Problematika rozhodování o mateřství zde byla sledována z perspektivy partnerství a partnerských vztahů jako důležitých podmínek jeho uskutečnění.

Výpovědi žen neodhalily vždy jasně formulovaná kritéria výběru partnera vhodného pro rodičovství. Je však zřejmé, že tato kritéria se mohou měnit spolu s věkem a v souvislosti $\mathrm{s}$ očekávaným naplněním jednotlivých životních fází. Zatímco v rané dospělosti ženy vstupovaly do partnerských svazků často bez perspektivy rodičovství, a tedy i nutnosti v těchto vztazích vytrvat, v období následujícím, kdy již má být mateřská role naplněna, zvažovaly takové vlastnosti partnera, které odpovídají dlouhodobému závazku - jako je spolehlivost, jistota, věrnost. Vymezení nové životní fáze (post-adolescence) klade však na ženy nárok včasného rozeznání jejich hranic a také schopnosti přizpůsobit své preference rozdílným požadavkům po sobě následujících životních etap. Pokud nedochází k hladkému přechodu jedné fáze do druhé, vnímají ženy tuto skutečnost jako vlastní selhání a neschopnost.

Fakt ustavování nové životní fáze může mít i nezamýšlené důsledky v podobě nabytí takových životních zkušeností, které mohou snadný přechod do mateřské fáze blokovat. V možnosti „,vyzkoušet si“ různé partnerské zkušenosti se skrývá past zvyšujících se nároků na partnera. Spolu s tím, jak žena nabývá zkušenosti a získává úspěchy v různých životních sférách, stává se nezávislejší a samostatnější. K tomu se může přidružovat přesvědčení žen o neschopnosti mužů samostatně jednat ve sfére domácnosti, ale i přeneseně pojímané jako přesvědčení o specifické závislosti mužů na ženách, např́iklad v oblasti rozhodování ve věcech vztahů, rodičovství nebo i financí. Toto povědomí získávají ženy jednak z vlastních zkušeností z dětství, z pozorování okolí, ale i ze svých partnerských vztahů. Kombinace vlastní dosažené nezávislosti a vědomí nerovnosti genderových rolí může vést $\mathrm{k}$ problémům v partnerství a při výběru partnera. 
Zároveň se však ukázalo, že v případě touhy po mateřství jsou ženy ochotny činit v tomto směru kompromisy a vstupovat do partnerských vztahů i s vědomím nerovnosti vyjádřené nejčastěji nerovnou dělbou prací mezi partnery v domácnosti a v péči o děti. Jinak je tomu na př́ikladu žen, které děti mít nechtějí. Zdá se, že volba bezdětnosti „osvobozuje“ ženy i od nutnosti přizpůsobovat se uspořádání partnerského vztahu, které je pro ně nevýhodné. Mohou proto volit takové formy vztahů, které jim zaručují určitou míru nezávislosti a také zachování jejich individuálního životního prostoru v podobě samostatného bydlení. Prodlužování tohoto životního způsobu a zvyk na něj pak může zpětně posilovat přesvědčení o bezdětnosti a jejích výhodách. Na prríkladu těchto žen také ztrácí význam vymezování životního běhu z perspektivy nové životní fáze. Charakteristiky s ní spojené nejsou těmito ženami vnímány jako dočasné, ale určují jejich pojetí dospělosti. I z tohoto důvodu je tedy př́značnější mluvit spíše než o prodlužujícím se mládí o nové definici dospělosti (Blatterer 2007, Blatterer 2010).

\section{Literatura}

ARNETT, J. Jeffrey. Emerging Adulthood. A Theory of Development From the Late Teens Through the Twenties. American Psychological Association, 2000, roč. 55, č. 5, s. 469-480. ISSN 0003-066X.

BARLOW, Anne; JAMES, Grace. Regulating Marriage and Cohabitation in $21^{\text {st }}$ Century Britain. Modern Law Review, 2004, roč. 67, č. 2, s. 143-176. ISSN 0026-7961.

BARTOŠOVÁ, Michaela; SLEPIČKOVÁ, Lenka. Problematické tranzice k mateřství. Sociální studia, 2008, roč. 5, č. 2, s. 35-54. ISSN 1214-813X.

BAUMAN, Zygmunt. Tekutá modernita. Praha: Mladá Fronta, 2002. 343 s. ISBN 8020409661.

BAXTER, Janeen. Patterns of Change and Stability in the Gender Division of Household Labour in Australia, 1986-1997. Joumal of Sociology, 2002, roč. 38, č. 4, s. 399-424. ISSN 1440-7833.

BAXTER, Janeen; HEWITT, Belinda; WESTERN, Mark. Post-Familial Families and the Domestic Division of Labour. Journal of Comparative Family Studies, 2005, roč. 36, č. 4, s. 583-604. ISSN 0047-2328.

BECK, Ulrich. Risk Society: Towards a New Modernity. Cambridge: Polity Press, 1992. 260 s. ISBN 080398345x.

BECK, Ulrich; BECK-GERNSHEIM, Elisabeth. The Normal Chaos of Love. Cambridge-Oxford: Polity Press, 1995. 231 s. ISBN 0745613829.

BECK-GERNSHEIM, Elisabeth. Reinventing the Family. In Search of New Lifestyles. Cambridge: Polity Press, 2002. 170 s. ISBN 0745622143.

BERRYMAN, Julia. Perspectives on Later Motherhood in Phoenix. In WOOLLETT, A, LLOYD, E. (eds.) Motherhood. Meanings, Practices and Ideologies. London: SAGE, 1991, s. 103-22. $240 \mathrm{~s}$. ISBN 0803983131.

BLATERRER, Harry. Contemporary Adulthood: Reconceptualizing an Uncontested Category. Current Sociology, 2007, roč. 55, č. 6, s. 771-792. ISSN 0011-3921.

BLATERRER, Harry. The Changing Semantics of Youth and Adulthood. Cultural Sociology, 2010, roč. 4, č. 1, s. 63-79. ISSN 17499755.

BUDGEON, Shelley. Couple Culture and the Production of Singleness. Sexualities, 2008, roč. 11, č. 3 , s. 301-325. ISSN 1363-4607.

BUDGEON, Shelley; ROSENEIL, Sasha. Editor's Introduction: Beyond The Conventional Family. Current Sociology, 2004, roč. 52, č. 2, s. 127-134. ISSN 0011-3921. 
CLARKBERG, Marin; STOLZENBERG, M. Ross; WAITE, J. Linda. Attitudes, Values and Entrance into Cohabitational versus Marital Unions. Social Forces, 1995, roč. 74, č. 2, s. 609-634. ISSN 0037-7732.

COLTRANE, Scott. Family Man: Fatherhood, Housework, and Gender Equity. New York: Oxford University Press, 1996. 304 s. ISBN 0195119096.

du BOIS-REYMOND, Manuela. 'I Don't Want to Commit Myself Yet': Young People's Life Concepts. Journal of Youth Studies, 1998, roč. 1, č. 1, s. 63-79. ISSN 1367-6261.

DUDOVÁ, Radka; VOHLÍDALOVÁ, Marta. Souvislosti promén pracovního trhu a forem soukromého, rodinného a partnerského života v české společnosti - teoretická studie. Praha: Sociologický ústav AV ČR, 2005. 166 s. ISBN 978-80-7330-119-4.

ELCHARDUS, Mark; SMITS, Wendy. The Persistence of the Standardized Life Cycle. Time \& Society, 2006, roč. 15, č. 2-3, s. 303-326. ISSN 0961-463X.

ETTLEROVÁ, Sylva; KUCHAŘOVÁ,Věra; MATĚJKOVÁ, Barbora; SVOBODOVÁ, Kamila; ŠŤASTNÁ, Anna. Postoje a zkušenosti s harmonizací rodiny a zaměstnání rodičů dětí předškolního a mladšiho školního věku. Praha: VÚPSV, 2006. 108 s. ISBN 80-87007-38-7.

GALLAND, Olivier. Précarité et entrées dans la vie. Revue Française de Sociologie, 1984, roč. 25, č. 1, s. 49-66. ISSN 0035-2969.

GIDDENS, Anthony. The Transformation of Intimacy: Sexuality, Love and Eroticism in Modern Societies. Cambridge: Polity, 1992. 216 s. ISBN 0804722145.

GORDON, Tuula. Single Women: On The Margins? Basingstoke: Macmillan, 1994. 224 s. ISBN 0333534824.

GROSS, Neil. The Detraditionalization of Intimacy Reconsidered. Sociological Theory, 2005, roč. 23, č. 3, s. 286-311. ISSN 1467-9558.

HAMPLOVÁ, Dana. (ed.) Děti na psí knižku? Mimomanželská plodnost v ČR. Praha: Sociologický ústav AV ČR, 2007. 155 s. ISBN 978-80-7330-128-6.

HAŠKOVÁ, Hana. Reprodukční preference a bezdětnost v české společnosti ve světle kvantitativních dat [online]. Proměny (kvantitativní výzkumy), 2005 [cit. 2008-03-31]. Dostupné na www: $<$ http:// soc.cas.cz/promeny/info/cz/25017/Kvantitativni-vyzkum.html>

HAŠKOVÁ, Hana; ZAMYKALOVÁ, Lenka. Mít děti - co je to za normu? Čí je to norma? Biograf, 2006, č. 40-41, s. 3-53. ISSN 1211-5770.

HEAT, Sue; CLEAVER, Elizabeth. Young, Free and Single? Twenty Something and Household Change. New York: Palgrave Macmillan, 2004. 225 s. ISBN 1403901244.

HOBSON, Barbara; OLAH, Livia. Birthstrikes? Agency and Capabilities in the Reconciliation of Employment and Family. Marriage \& Family Review, 2006, roč. 39, č. 3-4, s. 197-227. ISSN 0149-4929.

CHALOUPKOVÁ, Jana. Diferenciace motivů svobodného mateřství: proč neprovdané matky nevstoupily před narozením svého prvního dítěte do manželství? Data a výzkum - SDA Info, 2007, roč. 1, č. 2, s. 127-140. ISSN 1802-8152.

CHALOUPKOVÁ, Jana. Nejdřive dítě, potom svatba? Rodinné dráhy neprovdaných matek. Gender, rovné př́ležitosti, výzkum, 2011, roč. 12, č. 2, s. 30-40. ISSN 1213-0028.

CHANDLER, Joan. Women Without Husbands: An Exploration Of The Margins Of Marriage. London: Macmillan, 1991. 188 s. ISBN 0333513657.

CHARMAZ, Kathy. Constructing Grounded Theory. London: SAGE, 2006. 208 s. ISBN 0761973532.

JAMIESON, Lynn. Intimacy Transformed? A Critical Look at the ,Pure Relationship“. Sociology, 1999, roč. 33, č. 3, s. 477-494. ISSN 0038-0385.

JAMIESON, Lynn; SIMPSON, Roona; WASOFF, Fran. Solo-living Age 25-44: Subjectivities and Social Change. Paper for ASA Annual Conference, 2009. Centre for Research on Families and Relationship. 
KRAVDAL, Øystein. Does Marriage Require a Stronger Economic Underpinning than Informal Cohabitation? Population Studies, 1999, roč. 53, s. 63-80. ISSN 0032-4728.

KŘÍŽKOVÁ, Alena. Nepř́liš harmonická realita. Rodičovské kombinace práce a péče v mezích genderové struktury současné české společnosti. Gender, rovné přiležitosti, výzkum, 2007, roč. 8, č. 2, s. 60-67. ISSN 1213-0028.

LEWIS, Jane. Employment and Care: The Policy Problem, Gender Equality and the Issue of Choice. Journal of Comparative Policy Analysis, 2006, roč. 8, č. 2, s. 103-114. ISSN 1387-6988.

MAGUIRE, Meg; BALL, J., Stephen; McRAE, Sheila. Post-Adolescence, Dependence and the Refusal of Adulthood. Discourse, 2001, roč. 22, č. 2, s. 197-211. ISSN 0159-6306.

McDONALD, Peter. Gender Equity in Theories of Fertility Transition. Population and Development Review, 2000a, roč. 26, s. 3, s. 427-439. ISSN 0098-7921.

McDONALD, Peter. Gender Equity, Social Institutions and the Future of Fertility. Journal of Population Research, 2000b, roč. 17, č. 1, s. 1-15. ISSN 1443-2447.

MOLGAT, Marc; VÉZINA, Mireille. Transitionless Biographies? Youth and Representations of Solo Living. Young, 2008, roč. 16, č. 4, s. 349-371. ISSN 1103-3088.

MORGAN, David. Risk and Family Practices: Accounting for Change and Fluidity in Family Life. In SILVA, E. B., SMART, C. (eds.) The New Family? London: SAGE, 1999, s. 13-30. ISBN 076195855X.

OPPENHEIMER, Valerie. Women's Rising Employment and the Future of the Family in Industrial Societies. Population and Development Review, 1994, roč. 20, č. 2, s. 293-342. ISSN 0098-7921.

PLUG, Wim; ZEIJL, Elke; du BOIS-REYMOND, Manuela. Young People's Perceptions on Youth and Adulthood. A Longitudinal Study from The Netherlands. Journal of Youth Studies, 2003, roč. 6, č. 2 , s. 127-144. ISSN 1367-6261.

REYNOLDS, Jill; WETHERELL, Margaret. The Discursive Climate of Singleness: The Consequences for Women's Negotiation of a Single Identity. Feminism and Psychology, 2003, roč. 13, č. 4, s. 489-510. ISSN 0959-3535.

RICHTER, Rudolf. Post-adolescence as a New Phase in the Family Cycle? Innovation: The European Journal of Social Sciences, 1994, roč. 7, č. 1, s. 63-68. ISSN 1351-1610.

RINDFUSS, R. R. The Young Adult Years: Diversity, Structural Change, and Fertility. Demography, 1991, roč. 28, č. 4, s. 493-512. ISSN 0070-3370.

ROSENEIL, Sasha; BUDGEON, Shelley. Cultures of Intimacy and Care Beyond 'the Family': Personal Life and Social Change in the Early 21st Century. Current Sociology, 2004, roč. 52, č. 2, s. 135-159. ISSN 0011-3921.

SANDELOWSKI, Margarete; HOLDITCH-DAVIS, Diane; HARRIS, B. G. Living the Life: Explanations of Infertility. Sociology of Health and Illness, 1990, roč. 12, č. 2, s. 195-215. ISSN 0141-9889.

SANDFIELD, Anna; PERCY, Carol. Accounting for Single Status: Heterosexism and Ageism in Heterosexual Women's Talk about Marriage. Feminism and Psychology, 2003, roč. 13, č. 4, s. 475-488. ISSN 0959-3535.

SELTZER, Judith. Families Formed Outside of Marriage. Journal of Marriage and Family, 2000, roč. 62, č. 4, s. 1247-1268. ISSN 0022-2445.

SEVÓN, Eija. Timing Motherhood: Experiencing and Narrating the Choice to Become a Mother. Feminism and Psychology, 2005, roč. 15, č. 4, s. 461-482. ISSN 0959-3535.

SHARP, Elizabeth; GANONG, Laurence. Living in the Gray: Women's Experiences of Missing the Marital Transition. Journal of Marriage and the Family, 2007, roč. 69, č. 3, s. 831-844. ISSN $0022-2445$.

SILVA, Elizabeth, Bortolaia; SMART, Carol (eds.). The New Family? London: Sage, 1999. 192 s. ISBN 076195855X. 
SIMPSON, Roona. The Intimate Relationships of Contemporary Spinsters [online]. University of Edinburgh. Sociological Research Online, 2006, roč. 11, č. 3. Dostupné na www: <http://socresonline. org.uk/11/3/simpson.html>. ISSN 1360-7804.

SINGLY, Francois de (ed.) Etre soi parmi les autres. Paris: L'Harmattan, 2001a. 199 s. ISBN 2747501639.

SINGLY, Francois de; CHALAND, Karine. Quel modèle pour la vie à deux dans les sociétésmodernes avancées? In SINGLY, F. de, MESURE, S. (eds.) Le lien familial, Comprendre. Paris: Presses Universitaires de France, 2001b, s. 283-301. ISBN 213052268-8.

SMART, Carol; NEALE, Bren (eds.). Family Fragments? Cambridge: Polity Press, 1999. 222 s. ISBN 0745618944.

STRAUSS, Anselm; CORBIN, Juliette. Základy kvalitativního výzkumu. Boskovice: František Šalé Albert, 1999. 196 s. ISBN 808583460X.

TOMÁŠEK, Marcel. K genderovým zdrojům individualizačního habitu. Gender, rovné př́ležitosti, výzkum, 2006, roč. 7, č. 1, s. 11-15. ISSN 1213-0028.

TRIMBERGER, E. Kay. The New Single Woman. Boston: Beacon Press, 2006. 343 s. ISBN 0807065234.

VINKEN, Henk. New Life Course Dynamics? Career Orientations, Work Values and Future Perceptions of Dutch Youth. Young, 2007, roč. 15, č. 1, s. 9-30. ISSN 1047-9511

VOHLÍDALOVÁ, Marta; MAŘÍKOVÁ, Hana. Rozpady kohabitací, rozvody manželství: jiné a/nebo stejné sociální fenomény? Gender, rovné př́ležitosti, výzkum, 2011, roč. 12, č. 2, s. 3-16. ISSN 1213-0028.

WALLACE, Claire. How Old is Young and How Young is Old? Restructuring of age and the life course in Europe. Paper presented at Youth 2000 Conference, Middlesbrough, July 1995.

WESTERN, Marc and BAXTER Janeen. The Links between Paid and Unpaid Work: Australia and Sweden in the 1980s and 1990s. In BAXTER, J., WESTERN, M (eds.) Reconfigurations of Class and Gender. Stanford: Stanford University Press, 2001, s. 81-104. ISBN $0804738416,9780804738415$.

WOOLLETT, Anne; BOYLE, Mary. Reproduction, Women's Lives and Subjectivities. Feminism \& Psychology, 2000, roč. 10, č. 3, s. 307-311. ISSN 0959-3535.

ZEIJL, Elke. Young Adolescents' Leisure: A Cross-Cultural and Cross-Sectional Study of Dutch and German 10-15 Year-Olds. Opladen: Leske + Budrich, 2001. 213 s. ISBN 3810031224.

\section{Autorka}

Michaela Kvapilová Bartošová působí jako výzkumná pracovnice na Fakultě sociálních studií Masarykovy univerzity, kde v současné době dokončuje doktorské studium sociologie. $\mathrm{K}$ jejím odborným zájmům $\mathrm{v}$ oblasti sociologie rodiny patří problematika mateřské tranzice, bezdětnosti a singles. Zabývá se také sociologií dětství a podílí se na projektu, který prostřednictvím nových př́stupů $\mathrm{k}$ dětskému aktérovi a pomocí inovativních výzkumných technik zpracovává téma rodiny $\mathrm{z}$ pohledu dětí.

Kontakt: michba@volny.cz 